\title{
SISTEM PENDUKUNG KEPUTUSAN DALAM PEMBELIAN RUMAH MENGGUNAKAN METODE ANALYTICAL NETWORK PROCESS
}

\author{
Misrawi, Neva Satyahadewi, Hendra Perdana
}

\begin{abstract}
INTISARI
Pembelian rumah saat ini bukan hal yang sulit lagi, seiring perkembangan teknologi dewasa ini yang semakin berkembang. Fenomena ini menyebabkan banyak developer real-estate menawarkan begitu banyak keuntungan dan fasilitas pada pembeli rumah. Sebagai akibatnya, seseorang akan berhadapan dengan keputusan yang sangat kompleks untuk membeli sebuah rumah. Salah satu cara untuk menyelesaikan pengambilan keputusan dibutuhkan suatu metode untuk menganalisis pemilihan perumahan. Analytic Network Process (ANP) merupakan suatu metode yang dapat digunakan untuk menganalisis pengambilan keputusan pemilihan perumahan. Metode ini digunakan dalam bentuk penyelesaian dengan pertimbangan atas penyesuaian kompleksitas masalah secara penguraian sintesis disertai adanya skala prioritas yang menghasilkan pengaruh prioritas terbesar. Berdasarkan penelitian dapat diperoleh kesimpulan bahwa kriteria tipe rumah menjadi salah satu pertimbangan paling penting dalam pembelian rumah dengan nilai bobot 44,97\%. Kriteria Harga memiliki nilai bobot 43,63\% dan kriteria lokasi memiliki nilai bobot 11,40\%. Sedangkan pertimbangan paling penting ketika seluruh hubungan antar subkriteria dibandingkan yaitu Tipe Rumah 36 dengan nilai bobot 25,30\%. Dalam pemilihan pembelian rumah digunakan alternatif perumahan. Hasil analisis diperoleh Perumahan RBK menjadi alternatif pembelian rumah paling baik dengan nilai bobot paling tinggi yang sesuai kriteria dan subkriteria dengan nilai bobot 46,50\%.
\end{abstract}

Kata Kunci: ANP, Support Decision, Alternatif Perumahan.

\section{PENDAHULUAN}

Rumah adalah bangunan yang berfungsi sebagai tempat tinggal dan berkumpul suatu keluarga. Rumah juga merupakan tempat seluruh anggota keluarga berdiam dan melakukan aktivitas yang menjadi rutinitas sehari-hari. Rumah merupakan tempat berteduh atau berlindung dari panas, hujan dan hawa dingin, tempat untuk beristirahat, serta tempat berkumpul anggota keluarga. Hal itulah alasan bahwa memperoleh sebuah rumah harus direncanakan dengan baik.

Saat ini, kebutuhan akan tempat tinggal meningkat secara signifikan seiring dengan pertumbuhan penduduk. Fenomena ini menyebabkan banyak developer real-estate menawarkan begitu banyak keuntungan dan fasilitas pada pembeli rumah. Sebagai akibatnya, seseorang akan berhadapan dengan keputusan yang sangat kompleks untuk membeli sebuah rumah. Salah satu cara untuk menyelesaikan pengambilan keputusan maka dibutuhkan suatu metode untuk menganalisis keputusan pemilihan perumahan.

Metode ANP merupakan suatu metode yang dapat digunakan untuk menganalisis pengambilan keputusan pemilihan perumahan. Metode ini dikembangkan oleh Thomas L Saaty sebagai pendukung pengambilan keputusan. Metode ini digunakan dalam bentuk penyelesaian dengan pertimbangan atas penyesuaian kompleksitas masalah secara penguraian sintesis disertai adanya skala prioritas yang menghasilkan pengaruh prioritas terbesar[1]. Metode ANP juga mampu menjelaskan model faktorfaktor dependence serta feedback-nya secara sistematik. Pengambilan keputusan dalam metode ANP yaitu dengan melakukan pertimbangan dan validitas atas pengalaman empirical. Struktur jaringan yang digunakan yaitu benefit, opportunities, cost and risk membuat metode ini memungkinkan untuk mengidentifikasi, mengklasifikasi dan menyusun semua faktor yang mempengaruhi output atau keputusan yang dihasilkan.

Pada penelitian ini metode ANP akan digunakan untuk mencari prioritas alternatif solusi yang bias digunakan untuk menganalisis pengambilan keputusan pemilihan perumahan. Alternatif solusi serta kriteria yang akan digunakan diperoleh dari para narasumber yang merupakan orang-orang yang berkepentingan dalam pengembangan dan yang terlibat dalam pemilihan perumahan. 


\section{METODE ANALYTIC NETWORK PROCESS}

Metode Analytic Network Process (ANP) merupakan pengembangan dari metode Analytical Hierarchy Process (AHP). Metode ANP mampu memperbaiki kelemahan AHP berupa kemampuan mengakomodasi keterkaitan antar kriteria atau alternatif [2]. Keterkaitan pada metode ANP ada 2 jenis yaitu keterkaitan dalam satu set elemen (inner dependence) dan keterkaitan antar elemen yang berbeda (outer dependence). Adanya keterkaitan tersebut menyebabkan metode ANP lebih kompleks dibanding metode AHP. Metode ANP adalah salah satu metode yang mampu merepresentasikan tingkat kepentingan berbagai pihak dengan mempertimbangkan saling keterkaitan antar kriteria pada level struktur dan subkriteria yang ada [3].

\section{TAHAPAN ANALYTIC NETWORK PROCESS}

Yuksel dan Dagdeviren (2007) menjelaskan tahapan-tahapan yang harus dilakukan untuk mengerjakan ANP. Tahapan pertama yaitu konstruksi model dan penyusunan permasalahan. Bentuk permasalahan harus ditentukan dengan jelas dan kemudian disusun dalam sebuah sistem rasional yang berbentuk seperti jaringan. Kemudian tahapan kedua membuat matriks perbandingan berpasangan. Seperti halnya AHP, pada ANP setiap pasangan elemen keputusan di tiap kluster dibandingkan dengankriteria kontrolnya. Selain itu, sifat saling terkait antar kriteria dari tiap kluster juga perlu diperlakukan secara berpasangan; pengaruh dari tiap elemen terhadap elemen lain ini dapat direpresentasikan dalam eigen vector.

Tahapan selanjutnya adalah membentuk supermatriks. Dalam sebuah sistem dengan pengaruh yang saling terkait, vektor prioritas lokal dimasukkan ke dalam kolom yang sesuai dari sebuah matriks untuk mencapai prioritas global. Oleh karena itu, sebenarnya supermatriks adalah sebuah matriks yang terpartisi, dimana tiap segmen dari matriks merepresentasikan hubungan antar dua kluster pada sebuah sistem. Tahapan terakhir setelah mendapatkan nilai bobot prioritas masing-masing kriteria dan subkriteria, maka akan dilakukan penghitungan supermatriks dan rangking. Bobot prioritas dari kriteria dan alternatif dapat diketahui dari super-matriks yang telah dinormalisasi.

\section{MATRIKS PERBANDINGAN BERPASANGAN}

Matriks perbandingan berpasangan akan membandingkan semua elemen dalam bentuk berpasangan untuk setiap subsistem hirarki. Perbandingan tersebut kemudian ditransformasikan dalam bentuk matriks untuk maksud analisis numerik. Misalkan terdapat suatu subsistem hirarki dengan suatu kriteria $A$ dan sejumlah elemen dibawahnya $B_{1}$ sampai $B_{n}$. Perbandingan antar elemen untuk subsistem hirarki itu dapat dibuat dalam bentuk matriks $n \times n$. Matriks ini disebut matriks perbandingan berpasangan.

Nilai $b_{i j}$ adalah nilai perbandingan elemen $B_{i}$ terhadap $B_{j}$ yang menyatakan hubungan:

1. Seberapa jauh tingkat kepentingan $B_{i}$ bila dibandingkan dengan $B_{j}$,

2. Seberapa besar kontribusi $B_{i}$ terhadap kriteria A dibandingkan dengan $B_{j}$,

3. Seberapa jauh dominasi $B_{i}$ dibandingkan dengan $B_{j}$,

4. Seberapa banyak sifat kriteria A terdapat pada $B_{i}$ dibandingkan dengan $B_{i}$

Bila diketahui nilai $b_{i j}$ maka secara teoritis nilai $b_{j i}=1 / b_{i j}$, sedangkan $b_{i j}$ dalam situasi $i=j$ adalah mutlak. Nilai numerik yang digunakan untuk perbandingan pada tabel 1 diperoleh dari skala perbandingan yang dibuat Saaty. 
Tabel 1 Matriks Perbandingan Berpasangan untuk suatu kriteria A (Saaty, 2001)

\begin{tabular}{|l|l|l|l|l|}
\hline & $B_{1}$ & $B_{2}$ & $\cdots$ & $B_{n}$ \\
\hline$B_{1}$ & $b_{11}$ & $b_{12}$ & $\cdots$ & $b_{1 n}$ \\
\hline$B_{2}$ & $b_{21}$ & $b_{22}$ & $\cdots$ & $b_{2 n}$ \\
\hline$\vdots$ & $\vdots$ & $\vdots$ & & $\vdots$ \\
\hline$B_{n}$ & $b_{n 1}$ & $b_{n 2}$ & $\cdots$ & $b_{n n}$ \\
\hline
\end{tabular}

Tabel 2 Penilaian Perbandingan Berpasangan (Saaty, 2001)

\begin{tabular}{cll}
\hline $\begin{array}{c}\text { Tingkat } \\
\text { Kepentingan }\end{array}$ & \multicolumn{1}{c}{ Definisi } & \multicolumn{1}{c}{ Keterangan } \\
\hline 1 & Sama Penting & $\begin{array}{l}\text { Kedua elemen mempunyai pengaruh yang sama } \\
\text { Pengalaman dan penilaian sedikit memihak satu elemen } \\
\text { dibandingkan pasangannya } \\
\text { Pengalaman dan penilaian dengan kuat memihak satu } \\
\text { elemen dibandingkan pasangannya } \\
\text { Satu elemen sangat disukai dan secara praktis dominasinya } \\
\text { terlihat } \\
\text { Satu elemen terbukti mutlak lebih disukai dibandingkan } \\
\text { pasangannya } \\
\text { Ketika diperlukan sebuah kompromi } \\
\text { Jika elemen } i \text { memiliki salah satu angka di atas ketika } \\
\text { dibandingkan elemen } j, \text { maka } j \text { memiliki nilai kebalikan } \\
\text { ketika dibanding elemen } i .\end{array}$ \\
\hline
\end{tabular}

Rata-rata geometrik bertujuan untuk memberikan satu jawaban untuk matriks perbandingan berpasangan yang diperoleh dari semua responden. Rata-rata geometrik digunakan karena nilai yang diberikan responden bersifat perbandingan, sehingga lebih cocok digunakan dibanding rata-rata aritmatik. Proses ini diperoleh dengan cara masing-masing nilai yang diberikan responden harus dikalikan satu sama lain, kemudian dari hasil perkalian tersebut dipangkatkan $1 / N$ (Wirdianto dan Unbersa, 2008).

$$
a_{i j}=\left(B_{1} \times B_{2} \times \ldots \times B_{n}\right)^{1 / N}
$$

$a_{i j} \quad$ : Rata-rata geometrik perbandingan berpasangan antara $i$ dan $j$

$B_{i}$ : Nilai perbandingan berpasangan untuk responden ke- $i$, $i=1,2, \ldots, N$

$N \quad: \quad$ Jumlah responden

Langkah selanjutnya adalah menormalkan nilai rata-rata geometrik kemudian menghitung nilai bobotnya. Normalisasi data dilakukan dengan membagi nilai dari setiap elemen yang ada di dalam matriks perbandingan berpasangan dengan nilai total dari setiap kolom (Ardiansyah dan Siregar, 2016). Secara matematis dapat ditulis sebagai berikut:

$$
c_{i j}=a_{i j} / \sum_{i=1}^{n} a_{i j}
$$

$a_{i j} \quad$ : Rata-rata geometrik perbandingan berpasangan antara $i$ dan $j$

$c_{i j}:$ Normalisasi nilai rata-rata geometrik perbandingan berpasangan antara $i$ dan $j$ untuk $n$ responden 
Jika diasumsikan suatu sistem memiliki $K$ kriteria dimana elemen-elemen dalam tiap $i$ saling berinteraksi atau memiliki pengaruh terhadap beberapa atau seluruh kriteria yang ada. Jika kriteria dinotasikan dengan $C h$, dimana $h=1,2,3, \ldots, N$. Dengan elemen sebanyak $n h$ yang dinotasikan dengan $c h_{1}, c h_{2}, c h_{3}, \ldots, c h_{n h}$. Pengaruh dari satu set elemen dalam suatu kriteria pada elemen yang lain dalam suatu sistem dapat direpresentasikan melalui vektor prioritas berskala rasio yang diambil dari berbandingan berpasangan.

Setelah model dibuat, maka dilakukan pentabelan dari hasil data pairwise comparison dengan menggunakan tabel supermatriks. Pada Tabel 3 diperlihatkan format dasar tabel supermatriks.

Tabel 3 Format Dasar Supermatriks (Saaty, 2001)

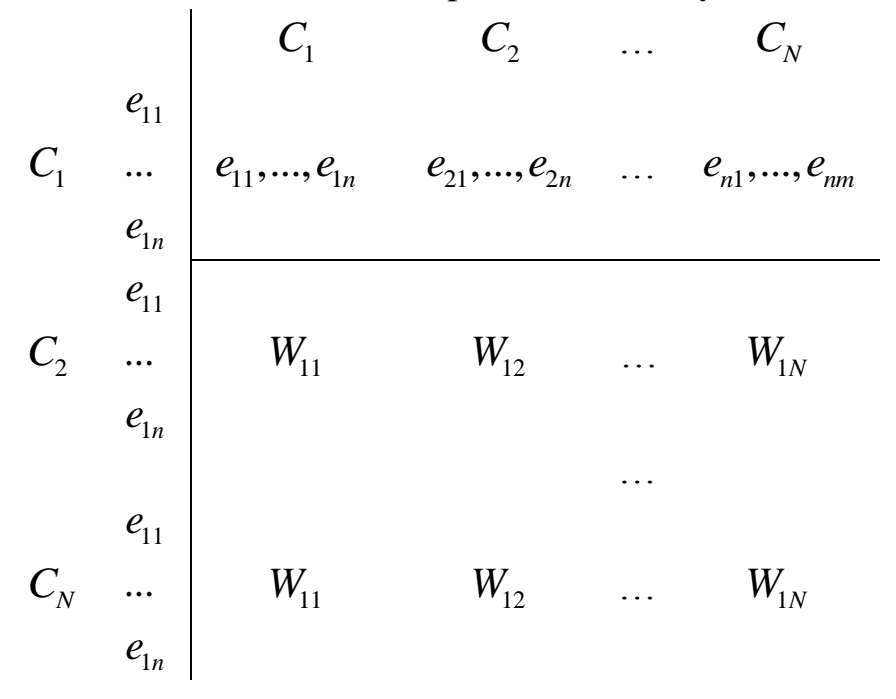

Blok $i$ dan $j$ dari matriks ini adalah:

$$
W=\left[\begin{array}{cccc}
w_{i 1}^{\left(j_{1}\right)} & w_{i 1}^{\left(j_{2}\right)} & \ldots & w_{i 1}^{\left(j_{n}\right)} \\
w_{i 2}^{\left(j_{1}\right)} & w_{i 2}^{\left(j_{2}\right)} & \ldots & w_{i 2}^{\left(j_{n}\right)} \\
\vdots & \vdots & \ddots & \vdots \\
w_{i n}^{\left(j_{1}\right)} & w_{i n}^{\left(j_{2}\right)} & \ldots & w_{i n}^{\left(j_{n}\right)}
\end{array}\right]
$$

Setelah melakukan proses pada Persamaan (3), kemudian akan dilakukan proses pembobotan untuk setiap kriteria yang telah ditentukan berdasarkan kriteria rekanan proyek. Algoritma perhitungan pembobotan yang dilakukan dimulai dari data dengan bentuk perbandingan berpasangan sampai dihasilkan bobot tiap indikator kriterianya. Kriteria dibuat berdasarkan kebutuhan dan tujuan dari pemilihan.

\section{MENGUJI KONSISTENSI JARINGAN}

Uji konsistensi data dilakukan untuk setiap matriks perbandingan tiap responden maupun hasil dari geometric mean. Dalam pembuatan keputusan penting untuk mengetahui seberapa baik konsistensi yang ada karena kita tidak dapat menginginkan keputusan berdasarkan pertimbangan dengan konsisten yang rendah. Hal-hal yang dapat dilakukan dalam mengukur tingkat konsistensi sebagai berikut: Mengalikan matriks awal tiap kriteria atau subkriteria dengan nilai bobot,

$$
\sum_{i=1}^{n} \sum_{j=1}^{n} a_{i j} w_{i j}
$$

Menjumlahkan nilai dari setiap baris pada matriks kemudian dibagi dengan nilai bobotnya, 


$$
X_{i j}=\frac{\sum_{i=1}^{n} \sum_{j=1}^{n} a_{i j} w_{i j}}{w_{i j}}
$$

Menjumlahkan hasil pembagian diatas kemudian dibagi dengan banyaknya elemen yang ada. Hasil pembagian tersebut dikenal dengan $\lambda_{\text {maks }}$.

$$
\lambda_{\text {maks }}=\frac{\sum_{i=1}^{n} \sum_{j=1}^{n} X_{i j}}{n}
$$

Pengumpulan pendapat antara satu faktor dengan yang lain adalah bebas satu sama lain. Hal ini dapat mengarah kepada ketidakkonsistenan jawaban yang diberikan responden. Namun terlalu banyak ketidak konsistenan juga tidak diinginkan. Pengulangan wawancara pada sejumlah responden yang sama kadang diperlukan apabila nilai tidak konsistennya besar.

Pada matriks konsisten, secara praktis $\lambda_{\text {maks }}=n$, sedangkan pada matriks tidak setiap variasi dari $a_{i j}$ akan membawa perubahan pada nilai $\lambda_{\text {maks }}$. Deviasi $\lambda_{\text {maks }}$ dari $n$ merupakan suatu parameter Consistency Index (CI) sebagai berikut:

$$
C I=\frac{\left(\lambda_{\text {maks }}-n\right)}{(n-1)}
$$

$$
\begin{array}{ll}
C I & : \text { Consistency Index } \\
\lambda_{\text {maks }} & : \text { Nilai eigen terbesar } \\
N & : \text { Jumlah elemen yang dibandingkan }
\end{array}
$$

Dengan membandingkan $C I$ dengan $R I$, maka didapatkan patokan untuk menentukan tingkat pkonsistensi suatu matriks, yang disebut dengan Consistency Ratio (CR), dengan rumus:

$$
C R=\frac{C I}{R I}
$$

$$
\begin{array}{ll}
\mathrm{CR} & : \text { Consistency Ratio } \\
\mathrm{CI} & : \text { Consistency Index } \\
\mathrm{RI} & : \text { Random Index }
\end{array}
$$

Tabel 4 Nilai rata-rata Random Index

\begin{tabular}{ccccccccccc}
\hline $\begin{array}{c}\text { Orde } \\
\text { Matriks }\end{array}$ & $\mathbf{1}$ & $\mathbf{2}$ & $\mathbf{3}$ & $\mathbf{4}$ & $\mathbf{5}$ & $\mathbf{6}$ & $\mathbf{7}$ & $\mathbf{8}$ & $\mathbf{9}$ & $\mathbf{1 0}$ \\
\hline RI & 0.00 & 0.00 & 0.52 & 0.90 & 1.12 & 1.24 & 1.32 & 1.41 & 1.45 & 1.49 \\
\hline
\end{tabular}

Saaty menerapkan bahwa suatu matriks perbandingan adalah konsisten bila nilai $C R$ tidak lebih dari 10\%[2]. Apabila rasio konsistensi semakin mendekati ke angka nol, berarti semakin baik nilainya dan menunjukkan kekonsistensian matriks perbandingan tersebut.

\section{STUDI KASUS}

Pengumpulan data dilakukan dengan cara menyebarkan kuesioner. Kuesioner dibuat berdasarkan perkembangan pembangunan perumahan yang semakin banyak dibangun di kota Pontianak dan kota lain disekitar Pontianak. Kuesioner disebarkan kepada responden ahli atau pakar ahli pada perumahan. Hal tersebut dilakukan agar penelitian terhadap pemilihan perumahan dapat menghasilkan keputusan yang baik. Para narasumber tersebut merupakan developer, manajer marketing perumahan, marketing perumahan dan konsumen perumahan. Narasumber Tersebut dianggap mempunyai pengetahuan tentang mengenai pemilihan dalam membeli rumah. 
Pertanyaan pada kuesioner terdiri dari beberapa kriteria dan subkriteria, yaitu

1. Level kriteria, terdiri dari harga rumah, lokasi perumahan dan tipe rumah.

2. Level subkriteria harga rumah terdiri dari harga 135 juta, 150 juta, 235 juta dan 280 juta.

3. Level subkriteria lokasi rumah terdiri dari dekat dengan prasarana Pendidikan, prasarana kesehatan, rumah ibadah, dan pasar rakyat

4. Level subkriteria tipe rumah terdiri dari tipe rumah 36 dan tipe rumah 45 .

Data untuk pengukuran prioritas kepentingan diperoleh melalui kuesioner yang dibagikan kepada 10 orang pakar ahli yang mengetahui faktor-faktor yang mempengaruhi masyarakat dalam membeli rumah. Data yang diperoleh kemudian dibuat matriks perbandingan berpasangan untuk tiap kriteria dan subkriteria. Pada Tabel 5 merupakan salah satu matriks perbandingan berpasangan pada level kriteria untuk responden ke-1.

Tabel 5 Matriks Level Kriteria Responden ke-1

\begin{tabular}{|l|l|l|c|}
\hline KRITERIA & \multicolumn{1}{|c|}{ Harga } & \multicolumn{1}{c|}{ Lokasi } & Tipe \\
\hline Harga & $a_{11}=1$ & $a_{12}=1$ & $a_{13}=3$ \\
\hline Lokasi & $a_{21}=1 / 1$ & $a_{22}=1$ & $a_{23}=3$ \\
\hline Tipe & $a_{31}=1 / 3$ & $a_{32}=1 / 3$ & $a_{33}=1$ \\
\hline
\end{tabular}

Responden ke-1 dalam membandingkan kriteria harga rumah dan lokasi perumahan memberikan penilaian sama penting untuk kedua kriteria. Sehingga pada $a_{12}=1$, sedangkan pada $a_{21}=1$ karena sifat berkebalikan matriks berpasangan. Perbandingan antara kriteria harga rumah dan tipe rumah, responden memberikan penilaian sedikit lebih penting untuk kriteria tipe rumah. Sehingga pada $a_{13}=3$, sedangkan pada $a_{31}=1 / 3$. Perbandingan antara kriteria lokasi rumah dan tipe rumah, responden memberikan penilaian sedikit lebih penting untuk kriteria tipe rumah. Sehingga pada $a_{23}=3$, sedangkan pada $a_{32}=1 / 3$. Setelah diperoleh matriks perbandingan berpasangan untuk seluruh responden serta masing-masing level kriteria dan subkriteria, maka akan dilakukan pembobotan dengan rata-rata geometri. Hal ini bertujuan untuk memberikan satu jawaban untuk matriks perbandingan berpasangan tiap level kriteria dan subkriteria yang diperoleh dari semua responden. Tabel 6 merupakan matriks perbandingan berpasangan pada level kriteria yang sudah dilakukan pembobotan dengan rata-rata geometri.

Tabel 6 Matriks level kriteria pembobotan dengan rata-rata geometrik

\begin{tabular}{|l|l|l|l|}
\hline KRITERIA & \multicolumn{1}{|c|}{ Harga } & \multicolumn{1}{c|}{ Lokasi } & Tipe \\
\hline Harga & $a_{11}=1$ & $a_{12}=0.9188$ & $a_{13}=4.4273$ \\
\hline Lokasi & $a_{21}=1.0884$ & $a_{22}=1$ & $a_{23}=3.4128$ \\
\hline Tipe & $a_{31}=0.2259$ & $a_{32}=0.2930$ & $a_{33}=1$ \\
\hline Jumlah & 2.3143 & 2.2118 & 8.8401 \\
\hline
\end{tabular}

Langkah selanjutnya adalah menormalkan nilai rata-rata geometrik kemudian menghitung nilai bobotnya. Tabel 7 menunjukkan bahwa pada level kriteria, harga rumah menempati prioritas utama terhadap pemilihan dalam membeli rumah dibandingkan dengan lokasi dan tipe rumah dengan bobot $44.95 \%$.

Tabel 7 Normalisasi matriks perbandingan berpasangan pada level kriteria

\begin{tabular}{|l|c|c|c|c|}
\hline KRITERIA & Harga & Lokasi & Tipe & Bobot \\
\hline Harga & 0.4310 & 0.4163 & 0.5011 & 0.4497 \\
\hline Lokasi & 0.4698 & 0.4525 & 0.3857 & 0.4363 \\
\hline Tipe & 0.0991 & 0.1312 & 0.1131 & 0.1140 \\
\hline
\end{tabular}


Kemudian dengan cara yang sama, dilakukan normalisasi matriks perbandingan berpasangan untuk level subkriteria sehingga diperoleh hasil sebagai berikut.

Tabel 8 Normalisasi matriks perbandingan berpasangan pada

level kriteria Tipe Rumah

\begin{tabular}{|c|c|c|c|}
\hline TIPE & Tipe 36 & Tipe 45 & Bobot \\
\hline Tipe 36 & 0.56 & 0.56 & 0.5627 \\
\hline Tipe 45 & 0.44 & 0.44 & 0.4367 \\
\hline
\end{tabular}

Tabel 8 menunjukkan bahwa pada level kriteria Tipe Rumah, Tipe 36 menempati prioritas utama terhadap pemilihan dalam membeli rumah dibandingkan dengan tipe 45 dengan bobot $56.27 \%$.

Tabel 9 Normalisasi matriks perbandingan berpasangan pada level kriteria Harga Rumah

\begin{tabular}{|c|c|c|c|c|c|}
\hline HARGA & 135 Juta & 150 Juta & 235 Juta & 280 Juta & Bobot \\
\hline 135 Juta & 0.25 & 0.44 & 0.18 & 0.34 & 0.3028 \\
\hline 150 Juta & 0.09 & 0.16 & 0.22 & 0.19 & 0.1610 \\
\hline 235 Juta & 0.54 & 0.27 & 0.39 & 0.30 & 0.3817 \\
\hline 280 Juta & 0.12 & 0.13 & 0.21 & 0.16 & 0.1545 \\
\hline
\end{tabular}

Tabel 9 menunjukkan bahwa pada level kriteria Harga Rumah, Harga 235 Juta menempati prioritas utama terhadap pemilihan dalam membeli rumah dibandingkan dengan harga lain dengan bobot 38.17\%. Pada Kriteria Lokasi Perumahan, Tabel 10, Aspek Prasarana Pendidikan menempati prioritas utama terhadap pemilihan dalam membeli rumah dibandingkan dengan kriteria lokasi lain dengan bobot $45.19 \%$.

Tabel 10 Normalisasi matriks perbandingan berpasangan pada level kriteria Lokasi Perumahan

\begin{tabular}{|l|c|c|c|c|c|}
\hline PRASARANA & Pendidikan & Kesehatan & Rumah Ibadah & Pasar Rakyat & Bobot \\
\hline Pendidikan & 0.47 & 0.46 & 0.51 & 0.36 & 0.4519 \\
\hline Kesehatan & 0.14 & 0.14 & 0.12 & 0.19 & 0.1457 \\
\hline Rumah Ibadah & 0.27 & 0.34 & 0.30 & 0.36 & 0.3164 \\
\hline Pasar Rakyat & 0.12 & 0.06 & 0.07 & 0.09 & 0.0860 \\
\hline
\end{tabular}

\section{KONSISTENSI RASIO}

Nilai bobot yang diperoleh dari normalisasi matriks perbandingan berpasangan, harus diuji tingkat konsistensinya terlebih dahulu sebelum ditetapkan sebagai prioritas. Hal ini dilakukan dengan melakukan perkalian antara matriks perbandingan berpasangan dengan rata-rata geometrik dengan nilai bobotnya. Berikut adalah perhitungan nilai konsistensi untuk level kriteria.

$$
\left[\begin{array}{lll}
1,0000 & 0,9188 & 4,4273 \\
1,0884 & 1,0000 & 3,4128 \\
0,2259 & 0,2930 & 1,0000
\end{array}\right]\left[\begin{array}{l}
0,4497 \\
0,4363 \\
0,1140
\end{array}\right]=\left[\begin{array}{l}
1,3553 \\
1,3148 \\
0,3434
\end{array}\right]
$$

Langkah selanjutnya adalah membagi nilai pada Persamaan (9) dengan masing-masing nilai bobotnya.

$$
\left[\begin{array}{l}
1,3553 / 0,4497 \\
1,3148 / 0,4363 \\
0,3434 / 0,1140
\end{array}\right]=\left[\begin{array}{l}
3,0138 \\
3,0135 \\
3,0125
\end{array}\right]
$$

Nilai rata-rata dari dari Persamaan (10) merupakan nilai eigen maksimal. 


$$
\begin{aligned}
\lambda_{\text {maks }} & =\frac{(3,0138+3,0135+3,0125)}{3} \\
& =3,0133
\end{aligned}
$$

Setelah mendapatkan nilai $\lambda_{\text {maks }}$ langkah selanjutnya adalah menghitung nilai indeks konsistensi.

$$
\begin{aligned}
C I & =\frac{\lambda_{\text {maks }}-n}{n-1} \\
& =\frac{3,0133-3}{3-1} \\
& =0,0067
\end{aligned}
$$

Jika $n=3$, pada Tabel 4 diperoleh nilai $R I=0,52$ maka diperoleh nilai rasio konsistensi seperti berikut:

$$
\begin{aligned}
C R & =\frac{C I}{R I} \\
& =\frac{0,0067}{0,52} \\
& =0,0129
\end{aligned}
$$

Karena nilai $C R, 0,0129<0,1000$, berarti penilaian responden konsisten dan bobot yang telah diperoleh dapat digunakan untuk penetapan prioritas. Dengan demikian diketahui bahwa para pakar ahli pada umumnya berpendapat bahwa harga merupakan kriteria yang perlu diperhatikan dalam penentuan faktor dalam pembelian rumah. Dengan cara yang sama dilakukan perhitungan untuk setiap level kriteria dan subkriteria.

Setelah mendapatkan pembobotan lokal pada tiap kriteria dan subkriteria, akan dilakukan

\begin{tabular}{|c|c|c|c|c|c|}
\hline Kriteria & $\begin{array}{l}\text { Bobot } \\
\text { (Rank) }\end{array}$ & Sub-Kriteria & $\begin{array}{l}\text { Bobot } \\
\text { Lokal }\end{array}$ & $\begin{array}{l}\text { Bobot } \\
\text { Global }\end{array}$ & Rank \\
\hline \multirow[t]{2}{*}{ Tipe } & \multirow{2}{*}{$\begin{array}{c}0.4497 \\
\text { (1) }\end{array}$} & Tipe 36 & 0.5627 & 0.2530 & 1 \\
\hline & & Tipe 45 & 0.4368 & 0.1964 & 3 \\
\hline \multirow[t]{4}{*}{ Harga } & \multirow{4}{*}{$\begin{array}{c}0.4363 \\
(2)\end{array}$} & 135 Juta & 0.4519 & 0.1972 & 2 \\
\hline & & 150 Juta & 0.1457 & 0.0636 & 5 \\
\hline & & 235 Juta & 0.3164 & 0.1380 & 4 \\
\hline & & 280 Juta & 0.0860 & 0.0375 & 7 \\
\hline \multirow[t]{4}{*}{ Lokasi } & \multirow{4}{*}{$\begin{array}{c}0.1140 \\
(3)\end{array}$} & Prasarana Pendidikan & 0.3028 & 0.0345 & 8 \\
\hline & & Prasarana Kesehatan & 0.1610 & 0.0184 & 9 \\
\hline & & Tempat Ibadah & 0.3817 & 0.0435 & 6 \\
\hline & & Pasar & 0.1545 & 0.0176 & 10 \\
\hline
\end{tabular}
pembandingan secara keseluruhan untuk mendapatkan bobot global. Proses analisis dibantu menggunakan Software Support Decision. Sebelum dilakukan analisis, dibuat bentuk jaringan (network) antara kriteria, subkriteria dan alternatif.

Tabel 10 menunjukkan hasil pembobotan lokal dan global dari seluruh tiap kriteria dan sub kriteria yang menjadi bahan pertimbangan dalam melakukan pembelian rumah. Perhitungan pada Tabel 10 menggunakan hasil analisis pada software Support Decision.

Tabel 10 Bobot Lokal dan Bobot Global

Berdasarkan bobot kriteria, dapat diperoleh kesimpulan bahwa kriteria tipe rumah menjadi salah satu pertimbangan paling penting dalam pembelian rumah dengan nilai bobot 0,4497 atau $44,97 \%$. Kriteria Harga memiliki bobot 0,4363 atau $43,63 \%$ dan kriteria lokasi memiliki bobot 0,1140 atau 
11,40\%. Sedangkan pertimbangan paling penting ketika seluruh hubungan antar subkriteria dibandingkan yaitu Tipe Rumah 36 dengan nilai bobot 0,2530 atau 25,30\%.

Dalam pemilihan pembelian rumah digunakan alternatif perumahan yaitu Perumahan RBK, Perumahan Alam Mulia, dan Perumahan Kota Raya. Setelah dilakukan perbandingan terhadap alternatif perumahan dengan memperhitungkan hubungan antar sub-kriteria dan kriteria, secara keseluruhan diperoleh hasil pada Tabel 11. Proses analisis menggunakan software Support Decision.

Berdasarkan Tabel 11 diperoleh Perumahan RBK menjadi Alternatif pembelian rumah paling baik yang sesuai kriteria dan subkriteria dengan nilai bobot 0,4650 atau 46,50\%. Kemudian perumahan Alam Mulia menempati alternatif kedua dengan bobot 0.3332 atau 33,32\%, dan terakhir perumahan Kota Raya dengan bobot 0,2018 atau 20,18\%.

Tabel 11 Bobot Penilaian Alternatif Perumahan

\begin{tabular}{|l|c|c|}
\hline \multicolumn{1}{|c|}{ Alternatif } & Bobot & Rank \\
\hline Perumahan Alam Mulia & 0.3332 & 2 \\
\hline Perumahan Kota Raya & 0.2018 & 3 \\
\hline Perumahan RBK & 0.4650 & 1 \\
\hline
\end{tabular}

\section{PENUTUP}

Berdasarkan hasil analisis data yang dilakukan maka dapat diambil kesimpulan bahwa metode analisis Analytic Network Process dapat diterapkan pada pengambilan keputusan pembelian rumah dengan mempertimbangkan berbagai kriteria, subkriteria dan alternatif. Berdasarkan bobot kriteria, dapat diperoleh kesimpulan bahwa kriteria tipe rumah menjadi salah satu pertimbangan paling penting dalam pembelian rumah dengan nilai bobot $44.97 \%$. Kriteria Harga memiliki nilai bobot $43.63 \%$ dan kriteria lokasi memiliki nilai bobot $11.40 \%$. Sedangkan pertimbangan paling penting ketika seluruh hubungan antar subkriteria dibandingkan yaitu Tipe Rumah 36 dengan nilai bobot $25.30 \%$ dibandingkan subkriteria lain.

Dalam pemilihan pembelian rumah digunakan alternatif perumahan yaitu Perumahan RBK, Perumahan Alam Mulia, dan Perumahan Kota Raya. Proses analisis dilakukan menggunakan software Support Decision untuk membandingkan alternatif perumahan dengan memperhitungkan hubungan antar sub-kriteria dan kriteria. Hasil analisis diperoleh Perumahan RBK menjadi Alternatif pembelian rumah paling baik yang sesuai kriteria dan subkriteria dengan nilai bobot 46,50\%. Kemudian perumahan Alam Mulia menempati alternatif kedua dengan nilai bobot 33,32\%, dan terakhir perumahan Kota Raya dengan nilai bobot 20,18\%.

\section{DAFTAR PUSTAKA}

[1]. Saaty, T. L. (1996). Decision Making with dependence and feedback: The Analytic Network Process. Pittsburgh: RWS-pubblications.

[2]. Saaty, T. L dan Vargas, L. G. (2001). Decision Making for Leaders: The Analytic Network Process for Decisions in a Complex World. Pittsburgh: RWS-pubblications.

[3]. Saaty, T. L dan Cillo, A. (2008). A Dictionary of Complex Decision Using the Analytic Network Process, The Encyclicon, Volume 2. Pittsburgh: RWS Publication

[4]. Pungkasanti, P. T., \& Handayani, T. 2017. Penerapan Analytic Network Process (ANP) Padda Sistem Pendukung Keputusan. Jurnal TRANSFORMATIKA, 14(2): 73-78

[5]. Pratama, A. Y. 2017. Analisis Dampak Kenaikan muka Air Laut Di Kabupaten kubu Raya Dan Kabupaten Mempawah dengan metode Analytical Hierarchy Process (AHP). Bimaster Unuversitas Tanjungpura Pontianak. 
[6]. Budiarti, S., \& Widodo, A. 2013. Pengambilan keputusan Multi-Kriteria menggunakan Metode ANP (Analytic Network Process) Pada Evaluasi Supplier. Jurnal mahasiswa Matematika

MISRAWI

NEVA SATYAHADEWI

HENDRA PERDANA
: Jurusan Matematika FMIPA UNTAN, Pontianak misrawi@student.untan.ac.id

: Jurusan Matematika FMIPA UNTAN, Pontianak neva.satya@math.untan.ac.id

: Jurusan Matematika FMIPA UNTAN, Pontianak hendra.perdana@math.untan.ac.id 